\title{
Trends in the european legislation on LDV pollutant emissions
}

\author{
The article presents current European homologation legislation regarding LDV emissions (as of 31.10.2008). New \\ legislation of the European Union: Euro 5 and Euro 6, that will be implemented in years to come, is also presented. The \\ system of emission compliance supervision, permissible values and measurement methodology have been dis-cussed. \\ Trends in the development of the above legislations in Europe have been presented.
}

Key words: ecology, emission legislation, passenger vehicles

\section{Kierunki zmian europejskich przepisów dotyczących emisji zanieczyszczeń z samochodów osobowych i dostawczych}

\begin{abstract}
$W$ artykule omówiono obecnie obowiazujace przepisy homologacyjne dotyczace emisji zanieczyszczeń z samochodów osobowych i dostawczych w Europie (wedtug stanu na 31.10.2008 r.). Przedstawiono także nowe przepisy Unii Europejskiej: Euro 5 i Euro 6, które będą stopniowo wprowadzane w najbliższych latach. Omówiono system kontroli zgodności z wymaganiami w zakresie emisji zanieczyszczeń, wartości dopuszczalne oraz metody pomiarów. Przedstawiono tendencje rozwoju tych przepisów w Europie.
\end{abstract}

Słowa kluczowe: ekologia, przepisy dotyczace toksyczności spalin, samochody osobowe

\section{Introduction}

The first regulations regarding vehicle emissions were introduced in the beginning of the 70's of the last century. The regulations concerned passenger vehicles and other vehicles of maximum mass not exceeding $3500 \mathrm{~kg}$. Ever since a large growth in the requirements for the above mentioned vehicles has bee observed.

The emission requirements are set forth in two types of regulations:

- those related to the type approval, hereinafter referred to as the homologation regulations (the manufacturer of the vehicles is responsible for compliance with these requirements),

- those related to the technical conditions of vehicles in operation (the owner or the user of the vehicles is responsible for compliance with these requirements).

The analysis performed herein is limited to the regulations on the homologation of vehicles of type $\mathrm{N}$ and $\mathrm{M}-$ LDV. In Europe the regulations are set forth in the following documents: EU Directives and EU Regulations as well as Regulations issued as addenda to the Geneva Convention of 1958 on homologation of vehicles [7], the signatories of which may be the states of the ECE UN, hereinafter referred to as ECE UN regulations.

The analysis performed herein refers to the legislation on pollutant emission binding at present (as of 31.10.2008) and the new legislation that the European Union has started to introduce. This new legislation sets up the emission requirements Euro 5 and Euro 6 for LDV that will be in force in years to come.

In the new legislation for the first time in history the terms "Euro" have been used. These terms were not used in any Directives and ECE UN regulations before. The division of

\section{Wprowadzenie}

Pierwsze przepisy dotyczące emisji zanieczyszczeń z pojazdów samochodowych wprowadzono w Europie na początku lat siedemdziesiątych ubiegłego stulecia. Odnosiły się one do samochodów osobowych i samochodów do przewozu ładunków o masie maksymalnej nieprzekraczającej $3500 \mathrm{~kg}$. Od tego czasu nastąpił znaczny wzrost wymagań odnośnie do ograniczenia emisji zanieczyszczeń z tych pojazdów.

Wymagania w zakresie emisji zanieczyszczeń są ustalone w dwóch rodzajach przepisów:

- dotyczących homologacji typu, zwanych dalej przepisami homologacyjnymi (za spełnienie tych wymagań jest odpowiedzialny producent pojazdu),

- dotyczących warunków technicznych pojazdów w eksploatacji (za spełnienie wymagań jest odpowiedzialny właściciel lub użytkownik pojazdu).

Analiza przeprowadzona w artykule jest ograniczona do przepisów homologacyjnych dla pojazdów kategorii M i N, należących do grupy pojazdów lekkich. W Europie przepisy te są ustalone w dyrektywach i rozporządzeniach Unii Europejskiej (UE) oraz w regulaminach wydanych jako załączniki do Porozumienia Genewskiego z 1958 r. w sprawie homologacji pojazdów [7], którego sygnatariuszami mogą być państwa należące do Europejskiej Komisji Gospodarczej (EKG) ONZ, zwanych regulaminami EKG ONZ.

Analizie poddano obecnie obowiązujące przepisy dotyczące emisji zanieczyszczeń według stanu na 31.10.2008 r. oraz nowe przepisy, które Unia Europejska zaczyna wprowadzać. Ustalają one dla pojazdów lekkich wymagania Euro 5 i Euro 6, które będą obowiązywały w najbliższych latach.

W nowych przepisach po raz pierwszy zastosowano oficjalnie termin „Euro”, do tej pory nieużywany ani w dyrektywach UE, ani w regulaminach EKG ONZ. Również 
$\mathrm{M}$ and $\mathrm{N}$ category into light and heavy duty vehicles were also officially introduced in the European legislation on emissions.

\section{Currently binding legislation for light duty vehicles}

It has been agreed that in the current regulations vehicles of maximum mass not exceeding $3500 \mathrm{~kg}$ are referred to as light duty vehicles i.e. the following homologation categories: $\mathrm{M}$ (most of the M1 vehicles and a fraction of M2; M3 vehicles of maximum mass greater than $3500 \mathrm{~kg}$ do not occur) and N1.

Current regulations on light duty vehicle emissions (Tab. 1) are set forth in the following documents: for homologation in EU-directive 70/220/ECE [2] amended by directive 2003/76/WE and for homologation in ECE UN in the regulation 83, 05 series of amendments [12].

The directive 70/220/ECE and regulation 83 apply to LDV of the homologation category $\mathrm{M}$ and N, fitted with SI engines fuelled with gasoline, LPG and $\mathrm{NG}$, and CI engines fuelled with diesel oil.

For vehicles of N1 category fitted with CI and SI engines fuelled with LPG and NG the manufacturer may choose the requirements. These could be either the requirements set forth in directive $70 / 220 / \mathrm{ECE}$ and regulation 83 or directive 2005/55/WE and regulation 49.

In the technical aspect the directive 70/220/ECE and regulation 83 are currently concurrent. Yet, from time to time they may show certain differences in requirements and testing methodology. Table 1 presents the principles of testing of $\mathrm{M}$ category vehicles of maximum mass not exceeding $3500 \mathrm{~kg}$ and the vehicles in the N1 category.

The emission requirements in type 1 test have been presented in Fig. 1 and Fig. 2.

Type 1 test is performed for vehicles in the category: 1) M1 of maximum mass not exceeding $3500 \mathrm{~kg}, \mathrm{M} 2$ of maximum mass not exceeding $3500 \mathrm{~kg}$ and N1, fitted with SI engines fuelled with gasoline, 2) M1 of maximum mass not exceeding $3500 \mathrm{~kg}$ and N1, fitted with SI engines fuelled with LPG and NG, 3) M1 of maximum mass not exceeding 3500 $\mathrm{kg}$ and $\mathrm{N} 1$, fitted with CI engines fuelled with diesel oil.

Type I test just like the types II and III has been included in the European regulations since the beginning of the legislation - the 1970's of the last century. Ever since substantial changes have been introduced in that legislation. The basic elements of this test have been modified: the testing principles, permissible values and methods of measurement. Current permissible emission values (Euro 4) from passenger vehicles fitted with SI engines fuelled with gasoline are lower than in 1970s. In the initial regulations by $25-46$ times for $\mathrm{CO}, 20-28$ times for $\mathrm{HC}$ and 34-46 times for $\mathrm{NO}_{x}$.

Stringency of emission requirements does not only depend on the permissible limits but also on other factors such as the testing and measurement methods. As a measure of stringency of a given requirement level the ratio of adjusted permissible values in the initial regulations to the current value for a given requirement level, called stringency index, podział pojazdów kategorii M i N na dwie grupy „lekkie” i „ciężkie” po raz pierwszy oficjalnie wprowadzano w przepisach europejskich dotyczących emisji zanieczyszczeń. Termin ,„pojazdy lekkie” zastosowano w artykule także przy analizie obecnie obowiązujących przepisów, mimo że nie jest w nich używany.

\section{Przepisy obecnie obowiązujące dla pojazdów lekkich}

Przyjęto umownie, że w obecnych przepisach do „lekkich” zalicza się pojazdy o masie maksymalnej nieprzekraczającej $3500 \mathrm{~kg}$, tzn. należące do kategorii homologacyjnych: M (większość samochodów kategorii M1 i niewielka część M2; pojazdy kategorii M3 o masie maksymalnej nieprzekraczającej $3500 \mathrm{~kg}$ nie występują) oraz N1.

Obecnie obowiązujące przepisy dotyczące emisji zanieczyszczeń dla pojazdów lekkich (tab. 1) są ustalone w następujących dokumentach:

W systemie homologacji UE w dyrektywie podstawowej 70/220/EWG [2] znowelizowanej przez dyrektywę 2003/76/ WE oraz w systemie homologacji EKG ONZ w regulaminie 83 , seria 05 poprawek [12].

Dyrektywa 70/220/EWG i regulamin 83 dotyczą pojazdów samochodowych lekkich, wyposażonych w silniki o ZI zasilane benzyną, LPG i NG oraz w silniki o ZS zasilane olejem napędowym.

Dla pojazdów kategorii N1 wyposażonych w silniki o ZS oraz w silniki o ZI zasilane LPG i NG producent może wybierać wymagania. Mogą to być wymagania ustalone w dyrektywie 70/220/EEC i regulaminie 83 , albo ustalone w dyrektywie 2005/55/WE i regulaminie 49.

Pod względem technicznym dyrektywa 70/220/EEC i regulamin 83 są obecnie zharmonizowane. Mogą jednak występować między nimi różnice zarówno w wymaganiach, jak i metodzie badań.

W tablicy 1 podano zasady badań pojazdów kategorii M o masie maksymalnej nieprzekraczającej $3500 \mathrm{~kg}$ oraz kategorii N1. Wymagania w zakresie emisji zanieczyszczeń w teście typu I przedstawiono na rys. 1 i 2.

Test typu I stosuje się do badań samochodów kategorii: 1) M1 o masie maksymalnej nieprzekraczającej $3500 \mathrm{~kg}$, M2 o masie maksymalnej nieprzekraczającej $3500 \mathrm{~kg}$ oraz kategorii N1, wyposażonych w silniki o ZI zasilane benzyną, 2) M1 o masie maksymalnej nieprzekraczającej $3500 \mathrm{~kg}$ oraz kategorii N1, wyposażonych w silniki o ZI zasilane LPG i $\mathrm{NG}, 3) \mathrm{M} 1$ o masie maksymalnej nie przekraczającej 3500 kg oraz kategorii N1, wyposażonych w silniki o ZS zasilane olejem napędowym.

Test typu I, podobnie jak testy typu II i III, występuje w przepisach europejskich od ich wejścia w życie na początku lat siedemdziesiątych XX w. Od tego czasu poczyniono w nim istotne zmiany dotyczące podstawowych elementów tego testu: zasady kontroli, wartości dopuszczalne i metoda pomiarów. Obecnie obowiązujące wartości dopuszczalne (Euro 4) emisji zanieczyszczeń z samochodów osobowych wyposażonych w silniki o ZI zasilane benzyną są mniejsze niż wprowadzone w latach siedemdziesiątych XX w. w 
Table 1. Emission test types as per directive 70/220/ECE and regulation 83 carried out within the homologation procedures for LDV

Tabela 1. Typy testów emisji wedlug dyrektywy 70/220/EWG i regulaminu 83 wykonywanych w ramach homologacji typu dla pojazdów lekkich

\begin{tabular}{|c|c|c|}
\hline Test type/typ testu & SI engines/silnik o ZI & CI engines/silnik o ZS \\
\hline $\begin{array}{l}\text { I: emission test on cold start in ambient temperature of } 20-30^{\circ} \mathrm{C} \text { in the } \mathrm{NEDC} \\
\text { cycle on a chassis dyno/I: pomiar emisji zanieczyszczen po zimnym rozruchu } w \\
\text { temperaturze otoczenia } 20-30^{\circ} \mathrm{C} \text { w cyklu NEDC na hamowni podwoziowej }\end{array}$ & \multicolumn{2}{|c|}{$\begin{array}{l}\text { Yes, requirements }- \text { Fig. } 1 \text { and Fig. } 2 / \\
\text { tak, wymagania - rys. } 1 \text { i } 2\end{array}$} \\
\hline $\begin{array}{l}\text { II: CO concentration test at idle/II: pomiar stężenia CO podczas pracy na biegu } \\
\text { jałowym }\end{array}$ & \multicolumn{2}{|l|}{$\mathrm{No} /$ nie } \\
\hline III: crankcase emission test/III: pomiar emisji ze skrzyni korbowej silnika & $\begin{array}{l}\text { Yes, requirement }-0 \text { emission/ } \\
\text { tak, wymagania }-0 \text { emisji }\end{array}$ & No/nie \\
\hline IV: fuel supply system emission test/IV: pomiar emisji z uktadu zasilania paliwem & $\begin{array}{l}\text { Yes, requirement to } 2 \mathrm{~g} \mathrm{HC} / \\
\text { tak, wymagania do } 2 \mathrm{~g} \mathrm{HC}\end{array}$ & No/nie \\
\hline $\begin{array}{l}\mathrm{V} \text { : aftertreatment unit durability test - mileage } 80,000 \mathrm{~km} / \mathrm{V} \text { : próba trwałości } \\
\text { urządzeń ograniczających emisję - przebieg } 80000 \mathrm{~km}\end{array}$ & \multicolumn{2}{|l|}{ Yes/tak } \\
\hline $\begin{array}{l}\text { VI: emission test on cold start in ambient temperature of }-7^{\circ} \mathrm{C} \text { in the UDC cycle } \\
\text { on a chassis dyno/pomiar emisji spalin } w \text { teście UDC na hamowni podwoziowej } \\
\text { w temperaturze }-7^{\circ} \mathrm{C}\end{array}$ & $\begin{array}{l}\text { Yes, requirement - Fig. } 5 / \\
\text { tak, wymagania - rys. } 5\end{array}$ & No/nie \\
\hline OBD test/kontrola działania układu OBD & \multicolumn{2}{|l|}{ Yes/tak } \\
\hline $\begin{array}{l}\text { Determining of the emission data required for technical inspection/określenie } \\
\text { danych o emisji wymaganych do badań technicznych }\end{array}$ & Yes/tak & No/nie \\
\hline
\end{tabular}

is taken. If we took into consideration the effects not only of the changes of the permissible values but also the modifications in the testing principles the stringency index valid for passenger vehicles fitted with SI engines fuelled with gasoline would grow to the level shown in Fig. 3.

Type III tests are carried out for light duty vehicles fitted with SI engines and test types IV for vehicles in the M1 category of maximum mass not exceeding $3500 \mathrm{~kg}$, M2 of maximum mass not exceeding $3500 \mathrm{~kg}$ and $\mathrm{N} 1$, fitted with SI engines fuelled with gasoline (including bifuel engines).

Type $\mathrm{V}$ test is carried out for all light duty vehicles. It consists in generating a mileage of $80,000 \mathrm{~km}$ on a test track or a chassis dyno in a special driving cycle. In the beginning of the procedure and then every $10,000 \mathrm{~km}$ a type I test is carried out in order to test the emission level. Based on the results for each emission component the factor of emission deterioration is determined $\left(\mathrm{DEF}_{\mathrm{i}}\right)$ by means of the following formula:

$$
\mathrm{DEF}_{\mathrm{i}}=\mathrm{M}_{\mathrm{i} 2} / \mathrm{M}_{\mathrm{i} 1} \text {, }
$$

where: $\mathrm{M}_{\mathrm{i} 2}$ - emission and the interpolated emission for the mileage of $80,000 \mathrm{~km}, \mathrm{M}_{\mathrm{i} 1}$ - emission and the interpolated emission for the mileage $6400 \mathrm{~km}$.

Type $\mathrm{V}$ test is carried out very rarely because the regulations allow fixed DEFs on manufacturer's consent as an alternative (Fig. 4).

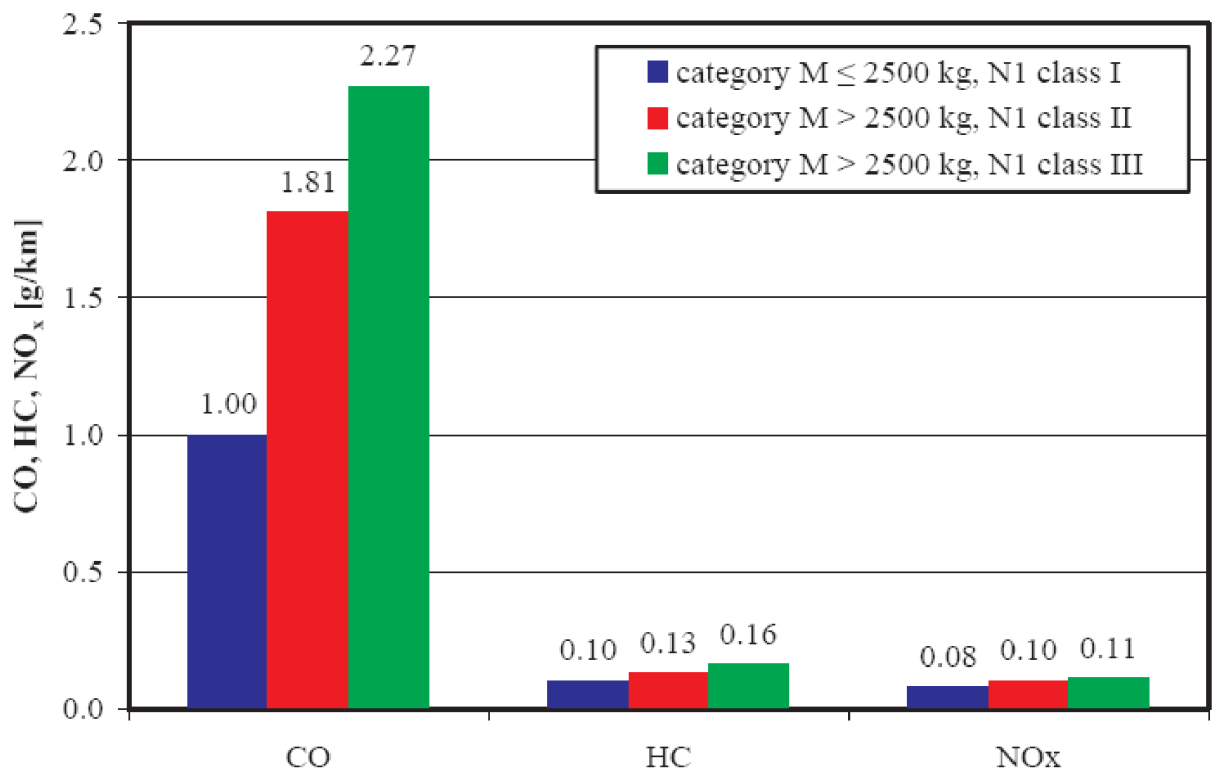

Fig. 1. Permissible emission values (Euro 4) in type 1 test for light duty vehicles fitted with SI engines Rys. 1. Wartości dopuszczalne emisji (Euro 4) w teście typu I dla pojazdów lekkich wyposażonych w silniki o ZI

pierwszych przepisach o 25-46 razy dla $\mathrm{CO}, 20-28$ razy dla $\mathrm{HC}$ oraz 34-46 razy dla $\mathrm{NO}_{\mathrm{x}}$.

Bardzo duże wymagania odnośnie do emisji zanieczyszczeń zależą nie tylko od wartości dopuszczalnych, lecz także od innych czynników, na przykład zasad kontroli i metod pomiaru. Jako wskaźnik surowości danego poziomu wymagań przyjmuje się często stosunek skorygowanych wartości dopuszczalnych w pierwszych przepisach dotyczących emisji i wartości dla danego poziomu. Jeśliby uwzględnić efekty nie tylko zmian wartości dopuszczalnych, lecz także zasad kontroli i metod pomiaru, to w przybliżeniu wskaźnik surowości wymagań obowiązujących obecnie dla samochodów osobowych wyposażonych w silniki o ZI zasilane benzyną wzrósłby do wartości przedstawionych na rys. 3 . 


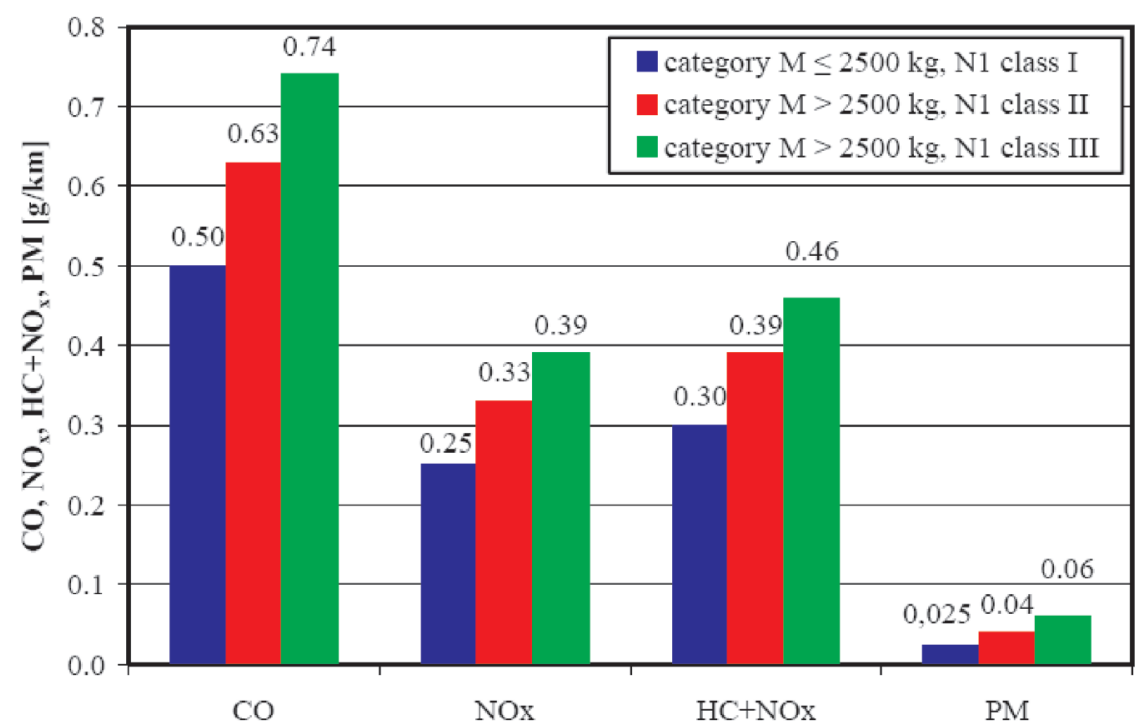

Fig. 2. Permissible emission values (Euro 4) in type 1 test for light duty vehicles fitted with CI engines Rys. 2. Wartości dopuszczalne emisji (Euro 4) w teście typu I dla pojazdów lekkich wyposażonych $w$ silniki o $Z S$

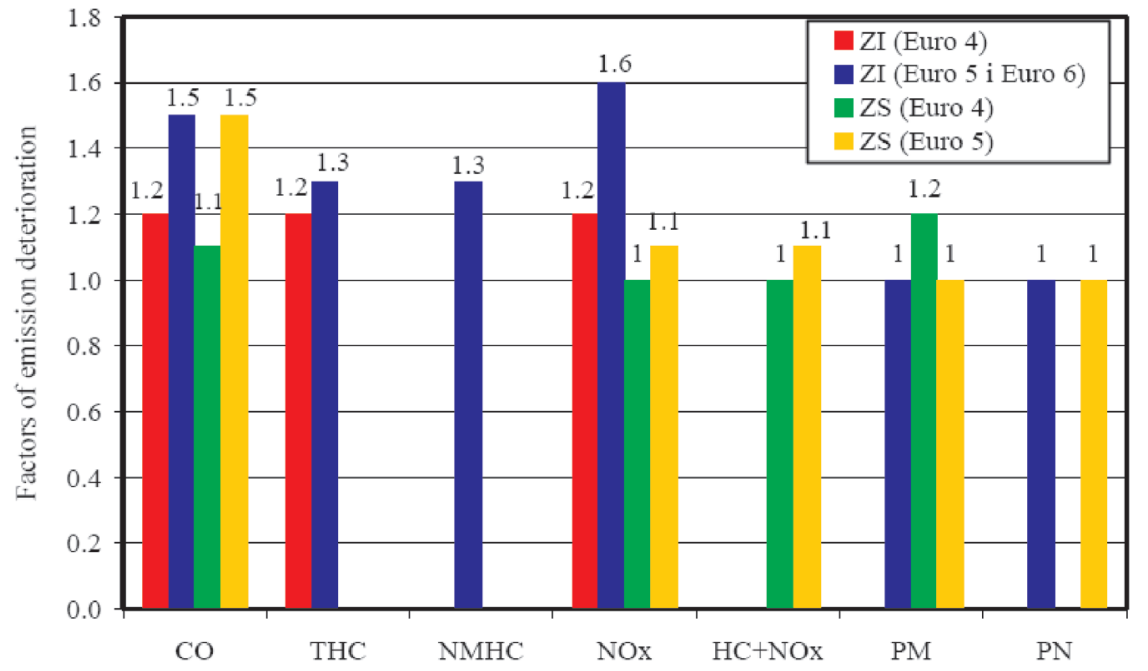

Fig. 3. Comparison of stringency index for CO, HC and NOx from 1970 through 2008 Rys. 3. Porównanie wskaźników surowości dla CO, HC i NO od 1970 do 2008 roku
Test typu III stosuje się do wszystkich samochodów lekkich wyposażonych w silniki o ZI, a test typu IV do samochodów kategorii M1 o masie maksymalnej nieprzekraczającej $3500 \mathrm{~kg}$, M2 o masie maksymalnej nieprzekraczającej $3500 \mathrm{~kg}$ i N1, wyposażonych w silniki o ZI zasilane benzyną (w tym także dwupaliwowych).

Test typu V stosuje się do wszystkich samochodów lekkich. Polega on na wykonaniu na torze lub hamowni podwoziowej przebiegu $80000 \mathrm{~km}$ w specjalnym cyklu jezdnym. Na początku przebiegu, a następnie co 10000 km, wykonuje się test typu I w celu pomiaru emisji zanieczyszczeń. Na podstawie wyników pomiarów określa się dla każdego zanieczyszczenia współczynnik pogorszenia emisji $\left(\mathrm{DEF}_{\mathrm{i}}\right)$ na podstawie wzoru (1),

gdzie: $\mathrm{M}_{\mathrm{i} 2}$ - emisja zanieczyszczenia $\mathrm{i}$ interpolowana dla przebiegu $80000 \mathrm{~km}, \mathrm{M}_{\mathrm{i} 1}$ - emisja zanieczyszczenia $\mathrm{i}$ interpolowana dla przebiegu $6400 \mathrm{~km}$.

Test typu $\mathrm{V}$ jest wykonywany bardzo rzadko, gdyż przepisy dopuszczają, jako alternatywę, stosowanie za zgodą producenta stałych współczynników pogorszenia emisji (rys. 4).

Test typu VI stosuje się do samochodów wyposażonych w silniki o ZI zasilane benzyną (w tym także dwupaliwowych). W tym przypadku występują istotne różnice między dyrektywą 70/220/EWG a regulaminem $83 \mathrm{w}$ zakresie ich stosowania. Według dyrektywy test typu

Type VI test is carried out for vehicles fitted with SI engines fuelled with gasoline (including bi-fuel engines). In this case, there are substantial differences in the application between directive 70/220/ECE and regulation 83. According to the directive, type VI test is carried out for all vehicles falling into the category of M1 of maximum mass not exceeding $3500 \mathrm{~kg}$ and N1. As per regulation 83 it is carried out only for vehicles falling into the category M1 and N1 whose maximum mass does not exceed $2500 \mathrm{~kg}$ or with seating capacity up to 6 persons. In the type VI test only the emission of CO and HC is limited (Fig. 5).

Currently, all light duty vehicles must be fitted with an OBD system monitoring malfunctions in systems having direct impact on the emissions. Detailed conditions of the tests and the malfunction are as follows:
VI stosuje się do wszystkich samochodów kategorii M1 o masie maksymalnej nieprzekraczającej $3500 \mathrm{~kg}$ i N1. Według regulaminu 83 stosuje się on tylko do samochodów kategorii M1 i N1, których masa maksymalna nie przekracza $2500 \mathrm{~kg}$ lub które są przeznaczone do transportu 6 . lub mniej osób. W teście typu VI ograniczeniu podlega tylko emisja tlenku węgla i węglowodorów (rys. 5).

Wszystkie samochody lekkie muszą być obecnie wyposażone w układ OBD sygnalizujący niesprawności w układach mających wpływ na emisję zanieczyszczeń. Warunki szczegółowe badań i kryteria decydujące o niesprawności pojazdów są następujące: 


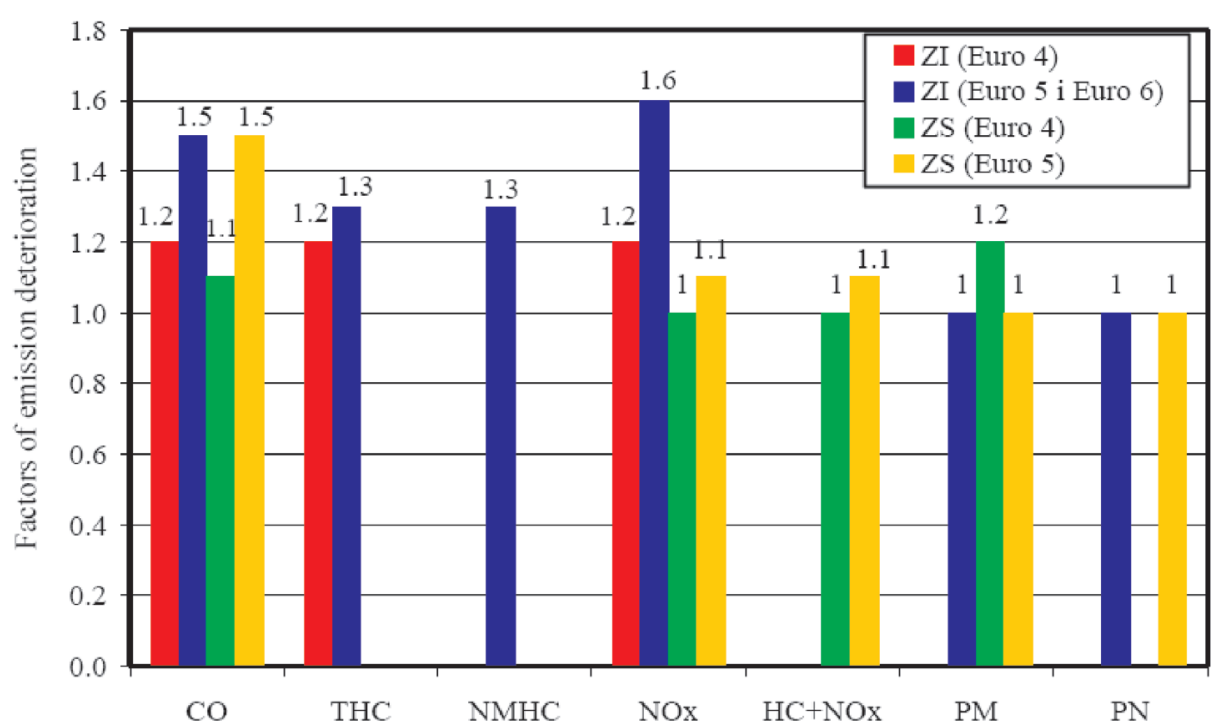

Fig. 4. Constant factors of emission deterioration set forth in Directive 70/220/ECE, EU Regulation 715/2007 and in ECE Regulation 83 for Euro 4-Euro 6 vehicles

Rys. 4. Stałe współczynniki pogorszenia emisji ustalone w dyrektywie 70/220/EWG, w rozporządzeniu $715 / 2007 i$ w regulaminie 83 dla pojazdów Euro 4-Euro 6
- $\quad$ samochody wyposażone w silniki o ZI: reaktor katalityczny (tylko HC), wypadanie zapłonów, czujnik stężenia tlenu, inne elementy kontrolujące emisję - wzrost emisji w teście typu I ponad wartość progową podaną na rys. 6; elementy układu napędowego wpływające na emisję, układ pochłaniania par paliwa - kontrola nieciągłości obwodu elektrycznego,

samochody wyposażone w silniki o ZS: reaktor katalityczny, inne elementy kontrolujące emisję (masowe natężenia przepływu powietrza, układ recyrkulacji spalin itp.) - wzrost emisji w teście typu I ponad
- SI engines: catalytic converter (HC only), misfire detection, oxygen sensor, other emission control devices - increase in the emission in type I test above the threshold value given in Fig. 6 as well as the components of the drive-train having impact on the emissions, EVAP system - electric circuit break monitoring.

- CI engines: catalytic converter, other emission control devices (mass air flow sensors, EGR etc.) such as: increase in the emission in type I test above the threshold value given in Fig. 7; components controlling the fuel quantity and injection time, elements of the drivetrain having impact on the emissions, PM filter - monitoring of electric circuit break and/or of permanent failure.

As per Directive 96/96/EC on technical inspections [6] the permissible values of $\mathrm{CO}$ for low emission vehicles fitted with SI engines measured at idle should equal those given by the manufacturer. Only in the case that these values are not available a constant maximum value of $0.3 \%$ vol. shall prevail. Yet, some of the manufacturers gave the maximum values even though the actual values for vehicle in good

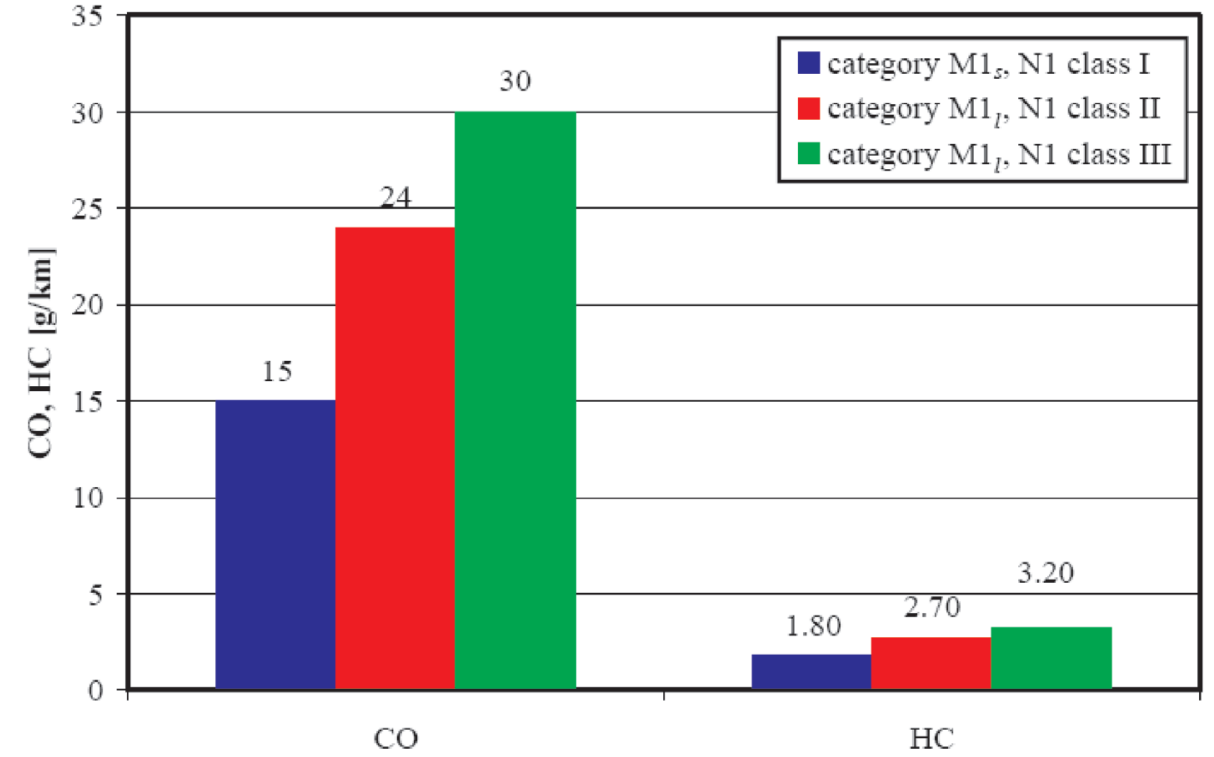

Fig. 5. Maximum permissible values in the type VI test as per Directive 70/220/ECE(M1 - category M1 with $\mathrm{MM} \leq 2500 \mathrm{~kg}$ and/or with not more than 6 seats; M1 - category M1 with MM $>2500 \mathrm{~kg}$ and/or with more than 6 seats)

Rys. 5. Wartości dopuszczalne emisji w teście typu VI wedtug dyrektywy 70/220/EWG (M1 - kategoria M1 o $M M \leq 2500 \mathrm{~kg}$ i/lub do przewozu nie więcej niż 6 osób, $M 1_{1}$ - kategoria M1 o MM> $2500 \mathrm{~kg}$ i/lub do przewozu więcej niż 6 osób)

wartość progową podaną na rys. 7; elementy wykonawcze sterowania dawką paliwa i czasem wtrysku, inne elementy układu napędowego wpływające na emisję, filtr cząstek stałych - kontrola nieciągłości obwodu elektrycznego i/lub całkowitego uszkodzenia.

Zgodnie z dyrektywą 96/96/EC dotyczącą badań technicznych [6] wartości dopuszczalne CO dla pojazdów niskoemisyjnych wyposażonych w silniki o ZI przy pracy 


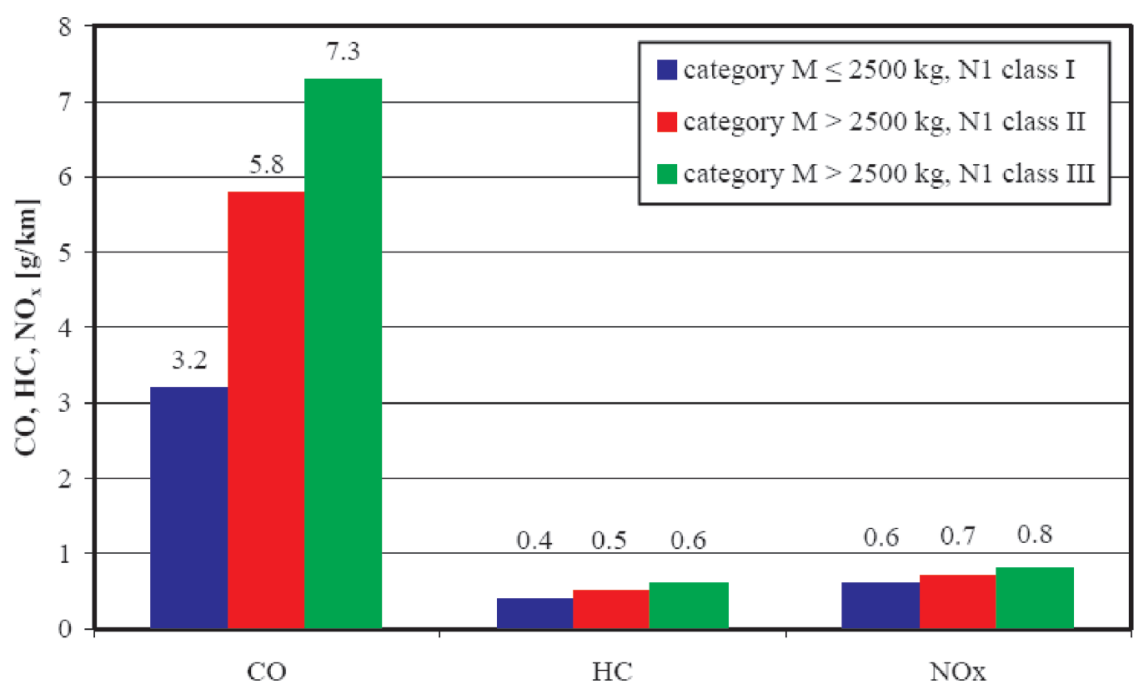

Fig. 6. Threshold limit values qualifying for malfunction in SI engines Rys. 6. Wartości progowe decydujące o niesprawności dla pojazdów wyposażonych w silniki o ZI

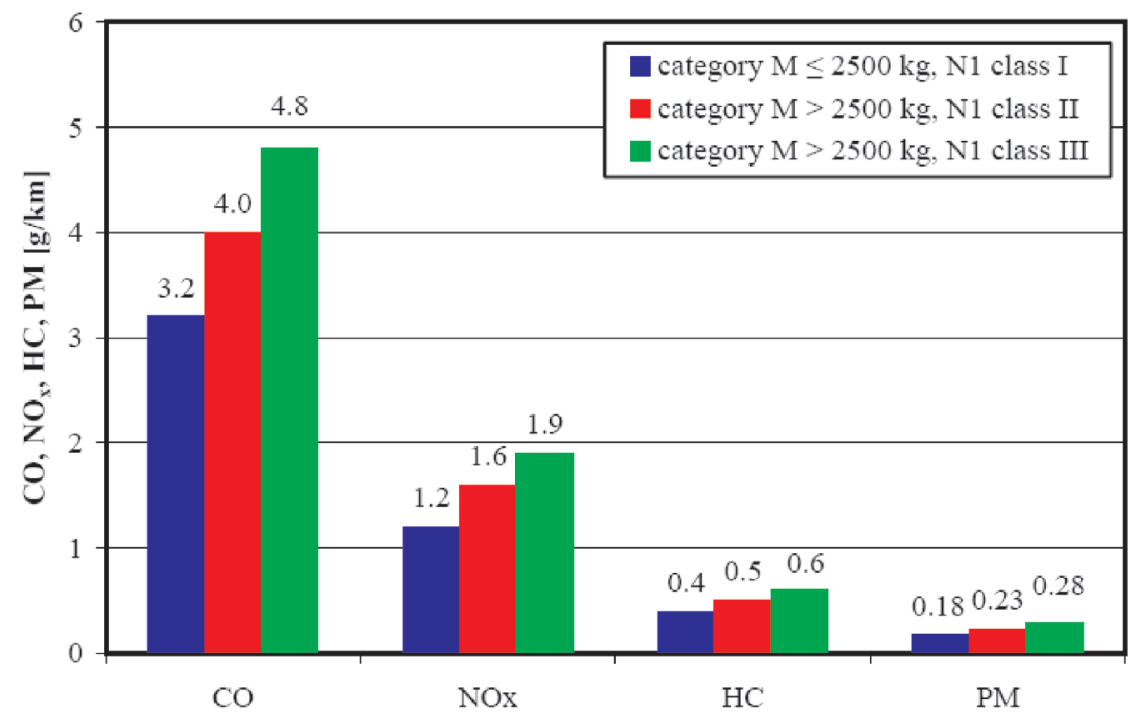

Fig. 7. Threshold limit values qualifying for malfunction in CI engines

Rys. 7. Wartości progowe decydujące o niesprawności dla pojazdów wyposażonych w silniki o ZS na biegu jałowym powinny być równe podanym przez producenta. Jedynie wtedy, gdy te wartości nie są dostępne obowiązuje ustalona w dyrektywie stała wartość maksymalna równa $0,3 \%$ obj. Część producentów podawała jednak wartości maksymalne, mimo że rzeczywiste wartości CO dla pojazdów w dobrym stanie technicznym były znacznie mniejsze, na ogół na poziomie $0,1 \%$ obj. Umożliwiało to wykonanie $\mathrm{z}$ wynikiem pozytywnym badań technicznych nawet $\mathrm{w}$ przypadku poważnych usterek elementów wpływających na emisję zanieczyszczeń. Określenie wartości dopuszczalnych w ramach badań homologacyjnych ma wyeliminować tę możliwość.

\section{Nowe przepisy UE}

Nowe przepisy UE dotyczace emisji zanieczyszczeń z pojazdów lekkich będą zawarte docelowo w następujących dokumentach:

- rozporządzeniu Parlamentu Europejskiego i Rady ustalającym wartości dopuszczalne emisji i ogólne zasady kontroli (rozporządzenie 715/2007 [11] wprowadzono w czerwcu 2007 r.),

- rozporządzeniu Komisji Europejskiej wdrażającym ww. rozporządzenie Parlamentu Europejskiego i Rady i ustalającym szczegółowe zasady kontroli: homologacji typu, kontroli zgodności produkcji i kontroli zgodności w eksploatacji (rozporządzenie 692/2008 [13] obowiązuje od lipca 2008 r.), -regulaminach 24, 83, $101 \mathrm{EKG}$ ONZ ustalających metody potechnical condition were much lower - usually on the level of $0.1 \%$ vol. This allowed passing the technical inspection even if there were serious malfunctions of components having impact on the vehicle emissions. The determining of the maximum permissible values within the homologation procedure is to eliminate this possibility.

\section{New UE legislation}

The European Union wants the new LDV emission legislation to be eventually comprised in the following documents:

- Regulation of the European Parliament and European Council setting forth the maximum permissible values of emissions and general principles of inspection (Regulation No. 715/2007 [11] became binding in June 2007), miaru emisji w poszczególnych testach (prace dotyczące nowelizacji regulaminów nie zostały jeszcze podjęte; w związku z tym niezbędne zmiany w metodyce są na okres przejściowy podane w wymienionym rozporządzeniu Komisji).

Dokumenty te zastąpią obecnie obowiązującą dyrektywę 70/220/EWG, a także dyrektywę 80/1268/EWG [4], dotyczącą metody pomiaru zużycia paliwa i emisji dwutlenku węgla, dyrektywę 72/306/EWG [3] dotyczącą zadymienia spalin oraz dyrektywę 80/1269/EWG [5] dotyczącą metody pomiaru mocy netto silnika. Należy podkreślić, że wymienione dwa rozporządzenia UE mają być przez kraje członkowskie stosowane bezpośrednio, bez konieczności przeniesienia do prawa krajowego. Obowiązujące dyrektywy są kierowane do państw członkowskich i wymagają transponowania. Rozpo- 
- Regulation of the European Commission implementing the said Regulation of the European Parliament and European Council; detailed principles of inspection will be set forth in it: type approval, conformity of production conformity in operation (Regulation 692/2008 [13] became binding in July 2008),

- Regulations 24, 83 and 101 ECE UN setting forth the methodology of emission measurement in particular tests (the works concerning the amending of this regulation have not yet been initiated, hence the necessary changes in the methodology for the transient period are provided in the said Commission Regulation).

The above documents will supersede the currently binding Directive 70/220/ECE as well as Directive 80/1268/ ECE [4] concerning the methodology of measurement, fuel consumption and CO2 emission, Directive 72/306/ECE [3] concerning exhaust opacity and Directive 80/1269/ECE [5] concerning the measurement of engine net power. It should be noted that the two mentioned EU Regulations are to be applied by the member states directly without transposing it into domestic legislation. The currently binding Directives are targeted at the member states and require transposing into a domestic legislation. Regulation 715/2007 sets forth two levels of requirements: Euro 5 and Euro 6 (Tab. 2). The European Commission in its rule additionally introduces interim levels, referred to as Euro 5+ and Euro 6-. They only apply to OBD systems, not the maximum permissible values of emissions.

Table 2. Date of implementation of particular requirement levels for LDV

Tabela 2. Daty wprowadzenia poszczególnych poziomów wymagań dla pojazdów lekkich

\begin{tabular}{|l|c|c|}
\hline $\begin{array}{l}\text { Requirement level/ } \\
\text { poziom wymagań }\end{array}$ & NTA* & ANR* \\
\hline Euro 5 & $1.09 .2009 / 1.09 .2010$ & $1.01 .2011 / 1.01 .2011$ \\
\hline Euro 5+ & $1.09 .2009 / 1.09 .2009$ & $1.09 .2009 / 1.09 .2009$ \\
\hline Euro 6 & $1.09 .2014 / 1.09 .2015$ & $1.09 .2015 / 1.09 .2016$ \\
\hline
\end{tabular}

* First date for vehicles of category M and N1 class I, second - for vehicles of category N1 class II and III and N2 as well as in the case of Euro 5 for vehicles designed to fulfill specific social needs. * Pierwsza data dla pojazdów kategorii M i N1 klasa I, druga - dla pojazdów kategorii N1 klasy II i III oraz N2, a także w przypadku Euro 5 dla pojazdów przystosowanych do spełnienia potrzeb socjalnych.

In the new legislation substantial changes have been introduced as compared to the currently binding one. The most important changes refer to the range of application, permissible values and testing. As per the new legislation the term "light duty vehicles" denotes motor vehicles of a reference mass (curb weight $+100 \mathrm{~kg}$ ) not exceeding 2610 $\mathrm{kg}$. The majority of vehicles in the homologation category M1, all N1 category vehicles and some part of the M2 and $\mathrm{N} 2$ category vehicles fall into the LDV group. The maximum mass of some of these vehicles exceeds $4500 \mathrm{~kg}$. Currently the term , light duty vehicles" (the term is in official use) denotes vehicles of maximum mass not exceeding $3500 \mathrm{~kg}$.

The new legislation will also cover vehicles fuelled with bio-fuels: bio-methane, ethanol and bio-diesel. rządzenie 715/2007 ustala dwa poziomy wymagań: Euro 5 i Euro 6 (tab. 2). Komisja Europejska wprowadza w swoim rozporządzeniu dodatkowo poziomy pośrednie, nazwane Euro 5+ i Euro 6-. Nie dotyczą one wartości dopuszczalnych emisji, lecz tylko systemów diagnostyki pokładowej.

W nowych przepisach będą wprowadzone znaczne zmiany w stosunku do obowiązujących obecnie. Najważniejsze z nich dotyczą zakresu stosowania, wartości dopuszczalnych oraz testów badawczych. Zgodnie z nowymi przepisami pod pojęciem „lekkie" rozumie się pojazdy samochodowe o masie odniesienia (masa własna $+100 \mathrm{~kg}$ ) nieprzekraczającej 2610 kg. Do grupy „lekkich” należy większość samochodów kategorii homologacyjnej M1, w zasadzie wszystkie samochody kategorii N1 oraz część samochodów kategorii M2 i N2. Masa maksymalna części tych samochodów przekracza $4500 \mathrm{~kg}$. Obecnie za „lekkie” (termin ten nie jest oficjalnie stosowany) uważa się samochody o masie maksymalnej nieprzekraczającej $3500 \mathrm{~kg}$.

Nowe przepisy będą także dotyczyły pojazdów zasilanych biopaliwami: biometanem, etanolem i biodieselem.

W nowych przepisach producenci pojazdów kategorii N1 wyposażonych w silniki o ZS oraz w silniki o ZI zasilane LPG i NG nie będą mieli możliwości wyboru wymagań, tak jak obecnie (albo wymagania ustalone w dyrektywie 70/220/EEC i regulaminie 83, bądź wymagania ustalone w dyrektywie 2005/55/WE i regulaminie 49). Zwiększa to surowość wymagań dla tych pojazdów.

W teście typu I ulegną zmniejszeniu wartości dopuszczalne emisji zanieczyszczeń $\mathrm{NO}_{\mathrm{x}}$ i PM (rys. 8 i 9). Zwiększona będzie liczba zanieczyszczeń objętych przepisami. Nowe wymagania będą dotyczyć także:

- węglowodorów niemetanowych (tylko dla pojazdów wyposażonych w silniki o ZI),

- liczby cząstek stałych PM (dla pojazdów wyposażonych w silniki o ZS i w silniki o ZI),

- masy cząstek stałych PM dla pojazdów wyposażonych w silniki o ZI z wtryskiem bezpośrednim paliwa.

W nowych przepisach położono nacisk na ograniczenie emisji cząstek stałych. Cząstki stałe, szczególnie te o wymiarach mniejszych niż około $0,1 \mu \mathrm{m}$, są obecnie uważane za zanieczyszczenie najgroźniejsze dla zdrowia człowieka. Wartości dopuszczalne dla masy tego zanieczyszczenia, jednakowe dla Euro 5 i Euro 6, ulegają zmniejszeniu 5-12 razy w stosunku do obecnie obowiązujących. Do spełnienia ustalonych wymagań niezbędne będzie stosowanie filtrów cząstek stałych. Część z tych filtrów ogranicza w sposób efektywny emisję masową tego zanieczyszczenia, lecz nie zatrzymuje cząstek o wymiarach mniejszych niż $0,1 \mu \mathrm{m}$. W celu zapobieżenia stosowania takich filtrów wprowadza się, jak podano wyżej, ograniczenia nie tylko masy, ale także liczby cząstek stałych. Wymagania co do liczby, a także masy cząstek stałych są jednakowe dla wszystkich pojazdów objętych nowymi przepisami, niezależnie od ich wielkości.

Zmniejszeniu ulegają także wartości dopuszczalne emisji tlenków azotu. Dla normy Euro 5 wynosi ono 25-30\%. Dalszemu ograniczeniu według normy Euro 6 ulega emisja tego zanieczyszczenia, lecz tylko dla pojazdów wyposażo- 
The new legislation for vehicles of N1 category fitted with CI engines and SI engines fuelled with LPG and NG will not allow the manufacturers to choose between the requirements, which is possible at present (either the requirements set forth in Directive 70/220/ECE and Regulation 83 or the requirements set forth in Directive 2005/55/WE and Regulation 49). It boosts the stringency of the requirements for these vehicles.

In type I test the monitored maximum permissible values of $\mathrm{NO}_{\mathrm{x}}$ and $\mathrm{PM}$ will be reduced (Fig. 8 and 9). More pollutants will be covered by the legislation. The new requirements will also cover:

- non-methane hydrocarbons (SI engines only),

- the number of particles PM (both SI and CI engines),

- the mass of particulates PM for vehicles fitted with SI direct fuel injection engines.

The new legislation places emphasis on the reduction of PM emission. PM smaller than $0.1 \mu \mathrm{m}$ in particular, are currently considered the most dangerous to human health.

Maximum permissible values for the mass of this pollutant (identical for Euro 5 and Euro 6) will be reduced by 5-12 times as compared with the current ones. In order to fulfill these requirements particulate filter application will be necessary. Some of these filters efficiently reduce the emission of this pollutant but does not trap particles smaller than $0.1 \mu \mathrm{m}$. In order to prevent the application of such filters a limit of permissible number of particles is enforced as stated above. The requirements as to the number and the mass of PM are identical for all vehicles under new legislation irrespective of their type.

The maximum permissible values of $\mathrm{NO}_{\mathrm{x}}$ emission will also be reduced. For Euro 5 it will be $25-30 \%$. A further limitation of this pollutant is instituted by Euro 6 but only for CI engines. The reduction of the permissible values as compared with Euro 5 is $56 \%$. nych w silniki o ZS. Zmniejszenie wartości dopuszczalnych w stosunku do Euro 5 wynosi 56\%. Wartości dopuszczalne dla CO i HC nie ulegają zmianie w stosunku do obecnie obowiązujących i są jednakowe dla Euro 5 i Euro 6.

Nowe przepisy podają dwie wartości dopuszczalne emisji masowej PM (rys. 8 i 9). Pierwsza z nich obowiązuje do dnia 31.09.2011 r. dla NTA i 31.12.2012 r. dla ANR, natomiast druga po tych datach. Zmiana ta nie wynika z zaostrzenia wymagań,

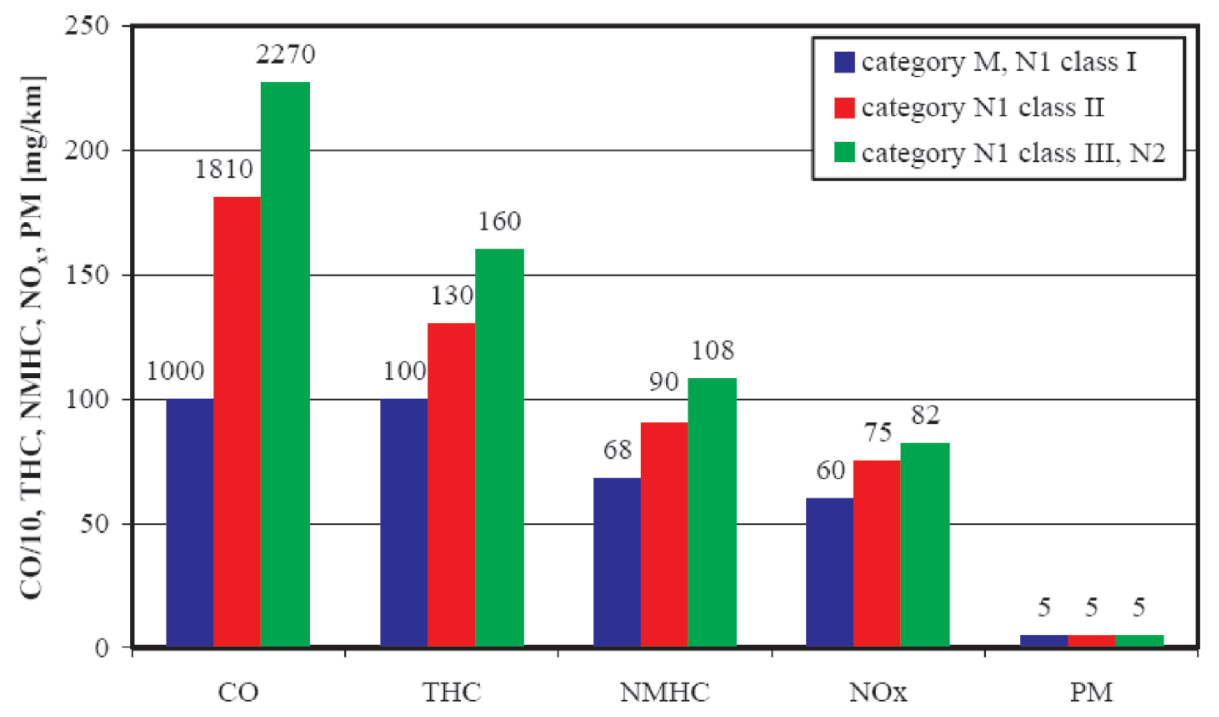

Fig. 8. Maximum permissible values of Euro 5 and Euro 6 in type I test for light duty SI vehicles; PM value (SI direct fuel injection engines only) will be in force until 31.09.2011 for NTA and 31.12.2012 for ANR, after these dates the PM values will amount to $4.5 \mathrm{mg} / \mathrm{km}$

Rys. 8. Wartości dopuszczalne emisji Euro 5 i Euro 6 w teście typu I dla pojazdów lekkich wyposażonych $w$ silniki o ZI; wartość PM (tylko dla pojazdów wyposażonych w silniki o ZI z wtryskiem bezpośrednim) obowiazuje do dnia 31.09.2011 r. dla NTA i 31.12.2012 r. dla ANR, po tych datach wartość PM wynosi 4,5 mg/km

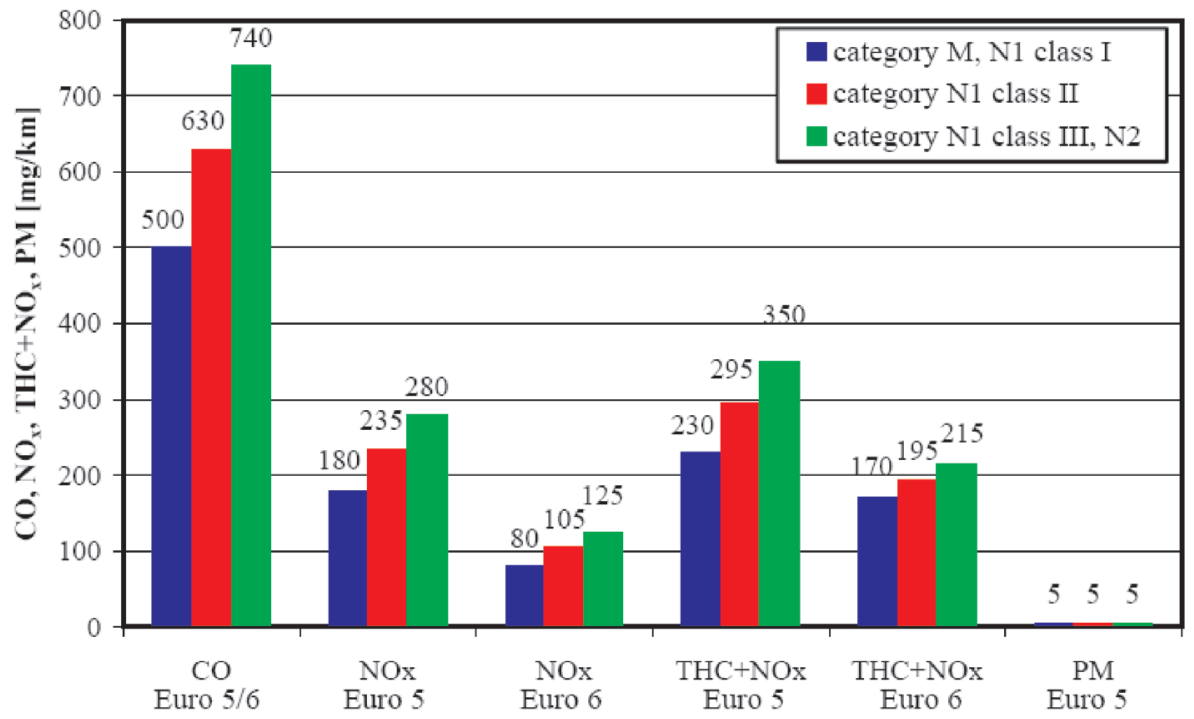

Fig. 9. Maximum permissible values of Euro 5 and Euro 6 in type I test for light duty SI vehicles; the PM values will be in force until 31.09.2011 for NTA and 31.12.2012 for ANR, after these dates the PM values will amount to $4.5 \mathrm{mg} / \mathrm{km}$; the PN value is $6 \cdot 10^{11} 1 / \mathrm{km}$

Rys. 9. Wartości dopuszczalne emisji Euro 5 i Euro 6 w teście typu I dla pojazdów lekkich wyposażonych w silniki o ZS; wartość PM obowiązuje do dnia 31.09.2011 r. dla NTA i 31.12.2012 r. dla ANR, po tych datach wartość PM wynosi $4,5 \mathrm{mg} / \mathrm{km}$; PN wynosi $6 \cdot 10^{11} 1 / \mathrm{km}$ 
The permissible values for $\mathrm{CO}$ and $\mathrm{HC}$ are not changed as compared with the current legislation and are the same for Euro 5 and Euro 6.

The new legislation provides two permissible values of mass PM emission (Fig. 8 and 9). The first will be in force until 31.09.2011 for NTA and 31.12.2012 for ANR and the latter - after these dates. This change does not result from the limitation of the requirements but from a modification of the testing methodology. The first value is permissible for the current methodology and the latter is permissible for the method modified to increase the accuracy of the measurement of low emission values.

Type III, IV and VI tests and their requirements are not subject to any changes in the new legislation. Type $\mathrm{V}$ test will undergo substantial changes though. The mileage generated in order to determine the DEF will be extended from 80,000 $\mathrm{km}$ to $160,000 \mathrm{~km}$. The alternative to apply constant DEFs is maintained, yet their value will be changed as compared with the current ones (see Fig. 4). High levels of emission coefficients for $\mathrm{CO}$ and $\mathrm{NO}_{\mathrm{x}}$ from $\mathrm{SI}$ vehicles and $\mathrm{CO}$ values for $\mathrm{CI}$ engines should be noted.

The legislation concerning the OBD operation will also undergo substantial changes. The threshold values at which malfunction indication should go on, decrease due to the reduction of the permissible values for type I test. The ratio of the threshold values to the permissible ones is also changed. It gives very stringent requirements for the aftertreatment systems in vehicles.

The requirement level of Euro 5+ differs from Euro 5 in terms of OBD. The differences are as follows:

- an OBD system complying with Euro 5+ must determine the so called diagnostic monitor realization coefficient for particular monitors in operation (IUMPR); it is the ratio of number of actually realized monitors to the number of situations when theoretically it should be realized; this coefficient should no be lower than the value set forth in the regulations; for most of the monitors this is 0.336 ,

- for SI engines the system should monitor the catalytic converter efficiency not only for $\mathrm{HC}$ but also for $\mathrm{NO}_{x}$ emissions,

- the threshold value for PM emissions for CI engines is lower in the case of Euro 5+.

Euro 6- differs from Euro 6 in that its threshold value for PM emissions in CI engines is higher.

It is a common opinion that the requirements set forth in the new legislation for type I test are not sufficiently rigorous and current level of technology allows a much larger reduction of emissions. This pertains particularly to $\mathrm{CO}$ and $\mathrm{HC}$, and to a lesser extent $\mathrm{NO}_{\mathrm{x}}$. For these pollutants the permissible values of emissions do not differ from the current ones (for $\mathrm{CO}$ and $\mathrm{THC}$ ) or are slightly lower (for $\mathrm{NO}_{\mathrm{x}}$ ). This opinion does not consider the fact that the stringency of requirements depends not only on the permissible values but also on other factors such as range of application, inspection and measurement methods. It is also of significant meaning that in the new legislation the DEFs are much higher, which, to a large extent, results from a higher mileage in type $\mathrm{V}$ lecz zmiany metody pomiarów. Pierwsza wartość dopuszczalna jest dla metody pomiaru stosowanej obecnie, druga natomiast dla metody zmodyfikowanej w celu zwiększenia dokładności pomiaru emisji dla małych stężeń składników.

Testy typu III, IV, VI i ustalone w nich wymagania nie ulegają zmianie w nowych przepisach. Znacznym zmianom ulegnie natomiast test typu V. Przebieg wykonywany w celu określenia współczynników pogorszenia emisji ulega zwiększeniu z $80000 \mathrm{~km}$ do $160000 \mathrm{~km}$. Jest zachowana możliwość stosowania stałych współczynników zamiast określonych na podstawie badań. Ich wartości ulegają jednak zmianie w stosunku do obecnie stosowanych (por. rys. 4). $\mathrm{Na}$ uwagę zasługują duże wartości współczynników dla emisji $\mathrm{CO}$ i NO $\mathrm{z}$ pojazdów wyposażonych $\mathrm{w}$ silniki o ZI i wartości $\mathrm{CO}$ dla pojazdów wyposażonych w silniki o ZS.

Znacznym zmianom ulegają przepisy dotyczące kontroli działania OBD. Wartości progowe, przy których powinna nastąpić sygnalizacja niesprawności, maleją w związku ze zmniejszeniem wartości dopuszczalnych dla testu typu I. Stosunek wartości progowych do dopuszczalnych także ulega zmianie. Stawia to bardzo rygorystyczne wymagania odnośnie do jakości układów ograniczenia emisji pojazdów.

Poziom wymagań Euro 5+ różni się od Euro 5 pod względem OBD. Różnice są następujące:

- układ OBD spełniający wymagania Euro 5+ powinien określać dla poszczególnych monitorów tzw. współczynnik realizacji monitora diagnostycznego w eksploatacji (IUMPR); jest to stosunek liczby przypadków, w których dany monitor był rzeczywiście zrealizowany, do liczby przypadków, w których teoretycznie powinien być zrealizowany; współczynnik ten powinien być nie mniejszy niż wartość ustalona w przepisach; dla większości monitorów wynosi ona 0,336 ,

- dla pojazdów wyposażonych w silniki o ZI układ ten powinien monitorować sprawność reaktora katalitycznego nie tylko pod względem emisji $\mathrm{HC}$, lecz także $\mathrm{NO}_{x}$, - wartość progowa dla emisji PM z pojazdów wyposażonych w silniki o ZS jest dla Euro 5+ mniejsza.

Euro 6- różni się od Euro 6 większą wartością progową dla emisji PM z pojazdów wyposażonych w silniki o ZS.

Często spotyka się opinie, że wymagania ustalone w nowych przepisach dla testu typu I nie są dostatecznie rygorystyczne i obecny poziom techniki pozwala na większe zmniejszenie emisji. Dotyczy to w szczególności CO i HC, a w mniejszym stopniu także $\mathrm{NO}_{x}$. Dla tych zanieczyszczeń wartości dopuszczalne emisji w nowych przepisach nie różnią się od obowiązujących obecnie (dla CO i THC), lub są od nich nieznacznie mniejsze (dla $\left.\mathrm{NO}_{x}\right)$. Opinie takie nie uwzględniają tego, że surowość wymagań zależy nie tylko od wartości dopuszczalnych, lecz także od innych czynników, np. od zakresu stosowania, zasad kontroli i metody pomiaru. Istotne znaczenie ma to, że w nowych przepisach wartości współczynników pogorszenia emisji są znacznie większe, co wynika w dużym stopniu $\mathrm{z}$ większego przebiegu w teście typu V, zaliczenia do „lekkich” pojazdów o masie maksymalnej większej niż $3500 \mathrm{~kg}$ oraz z tego, że nie występuje złagodzenie wymagań dla pojazdów kategorii M o masie 
test. Light duty vehicles include also those of maximum mass exceeding $3500 \mathrm{~kg}$ and there is no slackening of the requirements for vehicles of $\mathrm{M}$ category of maximum mass exceeding $2500 \mathrm{~kg}$ with the exception of vehicles designed to fulfill specific social needs.

\section{Conclusions}

Based on the analysis of current and planned legislation on emissions from LDVs of $\mathrm{M}$ and $\mathrm{N}$ category we can determine the basic trends in their development.

The new legislation on motor vehicle emissions constitutes one of the important elements of the air pollution strategy in the CAFE project (Clean Air for Europe) adopted by the European Commission in March 2001. This project determines the essential actions to be taken in the road transportation, energy, industry, agriculture and households in order to meet the set clean air requirements.

A constant tightening of the requirements on emissions takes place. So far 10 measurements of permissible values have been introduced for LDVs. Current permissible values are many times lower that those set forth in the initial emission regulations. For instance, in type I test for $\mathrm{CO}$ and $\mathrm{HC}$ emission from LDVs - the pollutants restricted in all the regulations to date - the permissible values were reduced by $25-46$ times and $20-28$ times respectively.

The number of tests within the type approval procedure is growing. In the initial regulations for LDVs only three tests were obligatory: emission test on cold start in the ambient temperature of $20-30^{\circ} \mathrm{C}$ in the UDC cycle on a chassis dyno (type I test), CO concentration test at idle (type II test) and crankcase emission test (type III test). Current legislation provides for 7 tests for LDVs. Stringency of emission requirements does not only depend on the permissible limits but also on other factors - measurement methods in particular. Modifications in the methodology influence the slackening/tightening of the requirements. It is estimated that the stringency index for $\mathrm{CO}$ and $\mathrm{HC}$ emissions from Euro 4 LDVs measured over type I test is 35-65 and 40-55 respectively. The actual reduction of emissions in the test conditions is higher that that resulting from the limiting of the permissible values.

For many years the system of vehicle control for pollutant emission comprised type approvals and conformity of production procedure. In 2000 an additional compliance in service procedure was introduced in the homologation legislation for LDVs that did not occur before. It was drawn on the one applied in the U.S. In-service compliance should be checked for a period up to 5 years or $100,000 \mathrm{~km}$, whichever is the sooner.

In the new legislation the so called vehicle life cycle i.e. mileage within which the vehicles must meet the set requirements in terms of emissions will be extended from $80,000 \mathrm{~km}$ to $160,000 \mathrm{~km}$.

\section{Abbreviations/Skróty i oznaczenia \\ ANR All New Registrations/wszystkie nowe rejestracje \\ CAFE Clean Air for Europe/program Czyste Powietrze dla Europy \\ CI compression ignition/zapton samoczynny}

całkowitej przekraczającej $2500 \mathrm{~kg}$, z wyjątkiem przystosowanych do spełniania potrzeb socjalnych.

\section{Podsumowanie}

$\mathrm{Na}$ podstawie analizy dotychczas obowiązujących i nowych przepisów dotyczących emisji zanieczyszczeń z lekkich pojazdów samochodowych kategorii M i N można określić podstawowe tendencje w ich rozwoju.

Nowe przepisy stanowią jeden z istotnych elementów strategii ograniczania zanieczyszczenia powietrza, zawartej w programie Czyste Powietrze dla Europy (Clean Air for Europe - CAFE), przyjętym przez Komisję Europejską w marcu 2001 r. Program ten określa działania niezbędne do podjęcia w sektorze transportu, w szczególności drogowego, energii, przemysłu, rolnictwa i gospodarstw domowych w celu spełnienia ustalonych wymagań w zakresie czystości powietrza.

Trwa ciągłe zaostrzanie wymagań w zakresie emisji zanieczyszczeń. Dotychczas dla pojazdów lekkich było wprowadzonych 10 pomiarów wartości dopuszczalnych. Obecnie obowiązujące wartości dopuszczalne są wielokrotnie mniejsze niż ustalone w pierwszych przepisach dotyczących emisji zanieczyszczeń. Przykładowo, w teście typu I dla tlenku węgla i węglowodorów z pojazdów lekkich, wartości dopuszczalne zanieczyszczeń, których emisja jest ograniczona we wszystkich przepisach wprowadzanych dotychczas, uległy zmniejszeniu odpowiednio 25-46 razy i 20-28 razy.

Wzrasta liczba testów, którym podlegają pojazdy w ramach homologacji typu. W pierwszych przepisach dla samochodów lekkich obowiązywały tylko trzy testy: pomiar emisji zanieczyszczeń po zimnym rozruchu w temperaturze otoczenia $20-30^{\circ} \mathrm{C}$ w cyklu UDC na hamowni podwoziowej (test typu I), pomiar stężenia CO podczas pracy na biegu jałowym (test typu II) oraz pomiar emisji ze skrzyni korbowej silnika (test typu III).

Według obecnych przepisów liczba obowiązujących testów dla pojazdów lekkich wynosi 7.

O surowości wymagań decydują nie tylko wartości dopuszczalne emisji, lecz także inne czynniki, w tym szczególnie metody pomiaru. Zmiany wprowadzone w tych metodach wpłynęły zarówno na zmniejszenie, jak i zwiększenie tej surowości. Szacuje się, że wskaźnik surowości wymagań Euro 4 w teście typu I dla emisji tlenku węgla i węglowodorów z pojazdów lekkich wynosi odpowiednio 35-65 oraz 40-55. Rzeczywiste ograniczenie emisji w warunkach testowych jest większe niż wynikające ze zmniejszenia wartości dopuszczalnych.

Przez wiele lat system kontroli pojazdów pod względem emisji zanieczyszczeń obejmował homologację typu i kontrolę zgodności produkcji. W przepisach homologacyjnych dla samochodów lekkich od 2000 r. wprowadzona jest dodatkowa, niewystępująca wcześniej, kontrola zgodności w eksploatacji, wzorowana na stosowanej od wielu lat w USA. Zgodność w eksploatacji jest sprawdzana przez okres 5. lat lub do przebiegu $100000 \mathrm{~km}$.

W nowych przepisach zostaje zwiększony z 80000 do $160000 \mathrm{~km}$ tzw. okres życia pojazdów wyrażony w formie przebiegu, w którym muszą one spełniać ustalone wymagania w zakresie emisji. 
$\mathrm{DEF}_{\mathrm{i}}$ factor of emission deterioration/współczynnik pogorszenia emisji

Euro European emission legislations and norms/europejskie przepisy toksyczności spalin

IUMPR diagnostic monitor realization coefficient for particular monitors in operation/współczynnik realizacji monitora diagnostycznego w eksploatacji

LDV Light Duty Vehicle

LPG Liquefied Petroleum Gas/ciekte paliwo gazowe (propanbutan)

M vehicles category, passenger cars (with buses)/kategoria pojazdów, samochody osobowe (łacznie z autobusami)

M1 vehicles category, passenger cars with no more than 8 seats (with a driver)/kategoria pojazdów, samochody osobowe do przewozu nie więcej niż 8 osób (tacznie z kierowca)

M11 category of M1 vehicles with the maximum total mass more than $2500 \mathrm{~kg}$ and/or with more than 6 seats/kategoria pojazdów M1 o dopuszczalnej masie catkowitej większej niż $2500 \mathrm{~kg}$ i/lub do przewozu więcej niż 6 osób

M1 category of M1 vehicles with the maximum total mass less or equal to $2500 \mathrm{~kg}$ and/or with no more than 6 seats/ kategoria pojazdów M1 o dopuszczalnej masie całkowitej mniejszej lub równej $2500 \mathrm{~kg}$ i/lub do przewozu nie więcej niż 6 osób

M2 vehicles category, buses with more than 8 seats and with the maximum total mass no more than $5000 \mathrm{~kg} /$ kategoria pojazdów, autobusy przeznaczone do przewozu osób o liczbie miejsc siedzacych dla pasażerów przekraczajacej 8 i o dopuszczalnej masie całkowitej nie większej niż $5000 \mathrm{~kg}$

M3 vehicles category, buses with more than 8 seats and with the maximum total mass more than $5000 \mathrm{~kg} /$ kategoria pojazdów, autobusy przeznaczone do przewozu osób o liczbie miejsc siedzacych dla pasażerów przekraczającej 8 i o dopuszczalnej masie całkowitej większej niz $5000 \mathrm{~kg}$

Mi1 emission and the interpolated emission for the mileage of $6400 \mathrm{~km} /$ emisja zanieczyszczenia i interpolowana dla przebiegu $6400 \mathrm{~km}$

$\mathrm{Mi} 2$ emission and the interpolated emission for the mileage of $80,000 \mathrm{~km} /$ emisja zanieczyszczenia $i$ interpolowana dla przebiegu $80000 \mathrm{~km}$

$\mathrm{N} \quad$ vehicles category, motor vehicles/kategoria pojazdów samochody ciężarowe

N1 vehicles category, motor vehicles with the maximum total mass no more than $3500 \mathrm{~kg} /$ kategoria pojazdów, samochody ciężarowe o maksymalnej masie całkowitej nie większej niż $3500 \mathrm{~kg}$

NEDC New European Driving Cycle/nowy europejski cykl jezdny - zmodyfikowany ECE R83 (tzw. Eurotest) z natychmiastowym poborem spalin

NG Natural Gas/gaz ziemny

NTA New Type Approvals/zatwierdzenie nowego typu

OBD On-Board Diagnostic/pokładowy system diagnozowania

PM Particulate Matter/czastki stałe

SI spark ignition/zaplon iskrowy

THC Total Hydrocarbons/calkowita emisja węglowodorów

UDC Urban Driving Cycle/miejski europejski cykl jezdny

\section{Bibliography/Literatura}

[1] Annex I Expert Group on the UN FCCC „Policies and Measures for Common Action. Transport Sector Studies. Part 3: Innovation for Sustainable Transport". OECD, October 1996.

[2] Council Directive 70/220/ECEof 20 March 1970 on the approximation of the laws of the Member States relating to measures to be taken against air pollution by gases from positive-ignition engines of motor vehicles. OJ L076, 06.04.1970.
[3] Council Directive 72/306/ECEof 2 August 1972 on the approximation of the laws of the Member States relating to the measures to be taken against the emission of pollutants from diesel engines for use in vehicles. OJ L 190, 20.8.1972.

[4] Council Directive 80/1268/ECEof 16 December 1980 on the approximation of the laws of the Member States relating to the fuel consumption of motor vehicles. Official Journal L 375, 31/12/1980.

[5] Council Directive 80/1269/ECEof 16 December 1980 on the approximation of the laws of the Member States relating to the engine power of motor vehicles. Official Journal L 375, 31/12/1980.

[6] Council Directive 96/96/EC of 20 December 1996 on the approximation of the laws of the Member States relating to roadworthiness tests for motor vehicles and their trailers. OJ L 46, 17.2.1997.

[7] Economic Commission for Europe. Inland Transport Committee. Agreement concerning the adoption of uniform technical prescriptions for wheeled vehicles, equipment and parts which can be fitted and/or be used on wheeled vehicles and the conditions for reciprocal recognition of approvals granted on the basis of these prescriptions. Revision 2 (including the amendments entered into force on 16 October 1995). ECE/TRANS/505.

[8] Economic Commission for Europe. Inland Transport Committee. Agreement concerning the establishing of global technical regulations for wheeled vehicles, equipment and parts which can be fitted and/or be used on wheeled vehicles. Done at Geneva on 25 June 1998. ECE/TRANS/132.

[9] Kruczyński S.W.: Trójfunkcyjne reaktory katalityczne. Warszawa-Radom 2004

[10] Międzyrządowy zespół do spraw zmian klimatu „Technologie, polityka i działania na rzecz zapobiegania zmianom klimatu". Instytut Ochrony Środowiska, listopad 1996.

[11] Regulation No. 715/2007 of the European Parliament and of the Council of 20 June 2007 on type approval of motor vehicles with respect to emissions from light passenger and commercial vehicles (Euro 5 and Euro 6) and on access to vehicle repair and maintenance information. OJ 1 171/1, 29.6.2007.

[12] Regulation No. 83: Uniform provisions concerning the approval of vehicles with regard to the emission of pollutants according to engine fuel requirements. E/ECE/324 E/ECE/ TRANS/505 Rev. 1/Add. 48/Rev. 3, 10 June 2005.

[13] Commission Regulation (EC) No 692/2008 of 18 July 2008 implementing and amending Regulation (EC) No 715/2007 of the European Parliament and of the Council on type-approval of motor vehicles with respect to emissions from light passenger and commercial vehicles (Euro 5 and Euro 6) and on access to vehicle repair and maintenance information.

Artykut recenzowany

Prof. Jerzy Merkisz, DEng. - Professor in the Faculty of Working Machines and Transportation at Poznan University of Technology.

Prof. dr hab. inż. Jerzy Merkisz - profesor na Wydziale Maszyn Roboczych i Transportu Politechniki Poznańskiej.

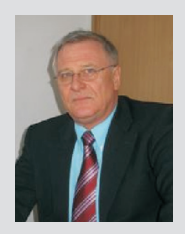

Mr. Stanisław Radzimirski, Ass. Prof., DEng. - Associated Professor in the Motor Transport Institute in Warsaw.

Doc. dr inż. Stanisław Radzimirski - docent w Instytucie Transportu Samochodowego w Warszawie.

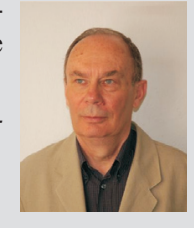

